\title{
Water governance for sustainable development: International practices and implications for the Mekong Delta region
}

\author{
THANG VO \\ University of Economics HCMC - thangvt@ueh.edu.vn. \\ THONG TRAN \\ Australian National University, Australia \\ DUY LUONG \\ University of Economics HCMC
}

ARTICLE INFO

Article history:

Received:

Nov. 22, 2016

Received in revised form:

Dec. 23, 2016

Accepted:

Oct. 25,2017

Keywords:

Water governance

Agriculture

Sustainable development

Mekong Delta

\section{ABSTRACT}

Water governance takes a vital role in sustainable development in the developing world. Population growth, economic development and technological improvement have raised the water demand but water supply is becoming unstable due to natural changes. Water scarcity leads to not only environmental pressures but also social tensions due to the fact that water resources are distributed unevenly across countries, regions, and social groups. In this paper, we firstly review water governance around the world and then investigate the water governance issues in Vietnam, especially in the Mekong Delta. International practices including tools, models and challenges of water governance would be valuable lessons for water policies in Vietnam. 


\section{Introduction}

While the concept of sustainable development refers to a link between economic growth and the environment, the concept of water governance relates to the capability of developing and implementing suitable policies for water. Literature shows that population growth, economic development and technological improvement have raised the water demand globally. Moreover, natural hazards like droughts and floods are intensifying the water stress. It is predicted that 2 billion people will be suffered from water scarcity by 2050 , and this number will rise to 3.2 billion people by 2080 . This results in conflicts not only at the inter-state level but also at the local community level. Therefore, water governance is often highlighted as a crucial component of development efforts and there is a general consensus about the necessity for "good water governance". It is noted that water governance is crucial for sustainable development for all countries worldwide, in particular, for developing countries.

This study points to the need for designing an effective water policy in Vietnam. There is concern that both water demand and supply in Vietnam are changing considerably, and affect the capability to maintain agricultural production seriously. This in turn influences not only the well-being of population in rural areas but also the goal of sustainable development in general term. Therefore, before elaborately investigating water governance in Vietnam for every particular aspect, it is necessary to present a broad overview of the issue. With this purpose, this policy paper reviews water governance around the world and then investigates the water governance issues in Vietnam, especially in the Mekong Delta. International practices and challenges in water governance would be valuable lessons for water policies in Vietnam. However, this study is just a starting point for the water governance topic, then it is worthy having a quantitative method for further research.

The structure of this study is organized as follows. In Section 2, we briefly review the concepts of sustainable development, water governance and discuss why these issues are crucial for development studies as well as policies. Section 3 provides an overview of the water governance in the world, particularly in Latin American and Caribbean countries and OECD countries. Water governance practices in Vietnam, including a background of water resources and current water management approaches, are discussed in Section 4, while Section 5 offers policy implications and conclusion.

\section{Sustainable development and water governance: Concepts and importance}

\subsection{Concept of sustainable development}

The concept of sustainable development refers to a link between economic growth and the environment. This term was initially mentioned in 1987 by the World Commission on Environment and Development. In the report of that commission, Our Common Future, sustainable development is defined as "development that meets the needs of the present without compromising the ability of future generations to meet their own needs" (Brundtland et al., 1987). Unlike the standard economics of growth and development, sustainable development analysis incorporates natural resources as a form of natural capital, described by the worth of the current stock of natural resources such as forests, sherries, water, mineral deposits, and the environment in general (Asefa, 2005). Unfortunately, various interpretations of sustainable development have 
made it far from being a practical instruction for development policy. However, this concept is moving toward a more comprehensive investigation into the link between economic development and environmental quality. For instance, the International Summit on Sustainable Development organized in Johannesburg, South Africa, in 2002 addressed some possibilities along this line (Hayward, 2003).

\subsection{Concept of water governance}

The term "water governance" was mentioned in the thesis that "the water crisis in the Asia region is essentially a crisis of water governance" by Tadao Chino, President of the Asia Development Bank in 2002. This term becomes popular from that time onward and was officially used in the publications of the World Bank, United Nations, International Institute of Administrative Sciences in 2008 and 2009 (Dukhovny \& Ziganshina, 2011).

The concept of water governance refers to "the capability of a social system to mobilize energies, in a coherent manner, for the sustainable development of water resources. The notion includes the ability to design public policies (and mobilize social resources in support of them) which are socially accepted, which have as their goal the sustainable development and use of water resources, and to make their implementation effective by the different actors/stakeholders involved in the process" (Rogers 2002).

One of the most cited definition of water governance is from Rogers and Hall (2003) in their contribution to the Global Water Partnership. They define water governance as "the range of political, social, economic and administrative systems that are in place to develop and manage water resources, and the delivery of water services, at different levels of society."

From this point of view, water governance must be transparent, open, accountable, participatory, communicative, incentive-based, sustainable, equitable, coherent, efficient, integrative and ethical (Solanes \& Jouravlev, 2006). And so, the level of water of governance is identified by the following:

The extent of consensus on the relations between water and society.

The extent of consensus on public policies relating to these relations.

The adequacy of administration systems that allow polices implement effectively toward the aim of sustainable development.

Therefore, water governance relates to the capability of developing and implementing suitable policies for water. It is noted that this capability is an outcome of both coherent management systems and sufficient administration. It in turn requires a solid foundation of institutions, laws, culture, understanding, practices as well as social participation and acceptance. In short, the key component of water governance is the ability to develop institutional arrangements along with the setting including limitations and expectations of the local system.

\subsection{Why water governance is important?}

According to Pahl-Wostl et al. (2008), water is a essential component of the earth system, influencing the interactions among human being, society and the nature. Freshwater is vital for human well-being in term of drinking water and sanitation, food security and health, industrial processes and energy supply. Hence, the need of water resources governance in times of global change creates one of the most challenging tasks for public policy around the world. Apparently, population growth, economic development and 
technological improvement have raised the water demand globally. This leads to not only environmental pressures but also social tensions due to the fact that water resources are distributed unevenly across countries, regions, and social groups. Moreover, natural hazards like droughts and floods are intensifying the water stress. Therefore, the increasing role of water governance is extensively documented by researchers in various disciplines, policymakers, as well as the general public.

From a publication of UNDP (2007), water scarcity is one the most serious problems challenging communities, countries and the world. This frequent occurrence is really affecting every continent. Around 1.2 billion people, or almost one-fifth of the world's population, live in areas of physical scarcity, and 500 million people are approaching this situation. Another 1.6 billion people, or almost one quarter of the world's population, face economic water shortage (where countries lack the necessary infrastructure to take water from rivers and aquifers). The number of regions which are short of water is increasing.

It is predicted that 2 billion people will be suffered from water scarcity by 2050 , and this number will rise to 3.2 billion people by 2080 (Dukhovny \& Ziganshina, 2011).

Literature on sustainable development indicates that water scarcity possibly results in conflicts not only at the inter-state level but also at the local community level (Cooley et al., 2009, Kundzewicz \& Kowalczak, 2009). It intensifies the current gap between the poor and the betteroff as freshwater is distributed unfairly and unequally against the vulnerable groups and the poor. For example, water level in Amu Darya River, Central Asia, halved during 2000-2001 resulted in the income loss of above 500 thousand people in the rural areas in the next 5 years. Furthermore, failures in water supply for the agricultural sector can lead to food insufficiency and unemployment. This has been indicated in reports on the farmers' life and irrigated farming productivity in Palestine and Bangladesh. Most arid zones across countries is suffering the same situation (Dukhovny \& Ziganshina, 2011).

While the concept of governance is widely employed in the water sector (Cosgrove \& Rijsberman, 2000; WWAP, 2003), efforts in this sector aiming to the achievement of the water and sanitation targets in the Millennium Development Goals (MDGs) will contribute to both poverty eradication and environmental sustainability (Franks \& Cleaver, 2007). Water governance is often highlighted as a crucial component of these development efforts and a general consensus about the necessity for "good water governance", as mentioned in the Ministerial Declaration of the Fourth World Water Forum (WWC 2006) and by other international agencies (DFID, 2005; UN, 2005). Recently, the Seventh World Water Forum (WWC 2015) has emphasized that "water governance is vital for sustainable development for all countries in the world, in particular, for developing countries including the least developed countries."

\section{Water governance around the world}

\subsection{Water governance at the interstate level}

To maintain sustainable water supply, first of all, countries have to guarantee a well-planned schedule of water delivery at the interstate level. While the upstream countries have geographical advantage to keep water for their hydropower production, the downstream countries need water mainly for agricultural irrigation which delivers means of subsistence for $60 \%$ of inhabitants in the region. Naturally, the upstream countries can define the water regime in the basin which 
mostly contradicts the existing agreement in the basin.

Currently, there are some examples of a wellorganized system of water allocation providing schedules of water delivery, supervising water quality, responding to natural condition changes. The International Joint Commission between US and Canada and the Rhine Commission are good examples. The operation of these two commissions are under the US-Canada Boundary Waters Treaty in 1909 and the Convention on Protection of the Rhine River in 1998, respectively. These agreements encourage the right and duties of riparian countries and commission's operation on the base of equality, transparency, and trust (Dukhovny \& Ziganshina, 2011). In Europe, a similar cooperation has been generated by the European Water Framework Directive (European, 2000) and the Directive on the Assessment and Management of Flood Risks (European, 2007).

Nevertheless, there are examples showing that water conflicts are likely to occur regardless of an interstate agreement and/or a basin water management organization. For example, although the operation of the Mekong River Commission has resulted in some positive outcomes and it is often cited as an example of basin collaboration, a sustainable consensus on river flows within the basin has not been achieved yet. Upstream countries like China and Myanmar have not involved in the consensus because they have plans to build dams upstream. In March 2009, when news that China was building dams on the upper reaches of the Indus River was released, there were protests against that project from Pakistan and India. Downstream countries have reasons to worry because this kind of upstream stations not only alters the natural flow of water but also increases water losses due to water leakage and vaporization from the reservoirs.

Operational coordination among upstream countries and downstream countries is far from enough, putting the latter into water stress. For instance, alongside the Euphrates River, water supply in Syria and Iraq is at risk while upstream Turkey gets the benefits. A lack of cooperation in the water use between upstream Israel and downstream Jordan and Palestine is another case. In Central Asia, the current conflicts of interests of four riparian countries (Kazakhstan, the Kyrgyz Republic, Tajikistan, and Uzbekistan) are connected to the flow of Syr Darya River and water discharge from the Toktogul catchment (Dukhovny \& Ziganshina, 2011).

\subsection{Water governance: Models and practices}

A study by OECD (2011) investigates institutional settings in governing water supply from selected OECD countries. Three categories regarding to the allocation of responsibilities to local regional government in water policy making include: (i) local and regional authorities' role do not exist or they take part in implementation of water policy only; (ii) local and regional authorities and central government play important role in designing and implementing water policies; (iii) local and regional authorities play the main role in water resources management and delivery of service (see Figure 1).

The first category includes countries where geographical and regional characteristics extremely vary such as United States, Canada, Belgium and Australia. According to the Constitution, Canadian provinces are granted with power to control the management of natural resources, including water. As a result, historical legacy and strong variation in geography and climatic conditions in the United States, local states take responsibilities in the allocation of water and in the regulation of water use instead of federal government. To control the allocation 
and use of water, permit systems are adopted as typical institutional arrangements in water policy. In Belgium, the local and regional authorities design and implement water policy as well as coastal and territorial waters, including infrastructure and fisheries. Belgian local government also make policies regarding to land development, nature conservation, public works and transportation. In Australia, every state and territorial jurisdiction have their own legislation and regulation for water governance from management and service delivery of water and wastewater.The second category consists of countries where the central government and the local governments play the same significant role in the design and implementation of water policies. This category is found in most European countries where there is an institutional framework at national level for setting priorities for water policy such as laws and decrees. Under this policy framework, central government set rules for the delivery of water and wastewater service, i.e. pricing, while local government design economic regulation as complementary policy. All revenues from water and wastewater service are regulated by central government and then set up by the relevant local and regional authorities. An example in this category is New Zealand where central government prepares national design and regulations for water and wastewater policy. In addition, central government also support and monitor local authorities in enforcing policy based on national plans.

The third category comprises countries where local and regional authority's role is mainly to implement water policy rather than participate in the design stage. Israel, Chile and Korea are typical countries of centralized water policy making process. Under this institutional setting, local government only role is to implement water policy designed at central government level. There is no river basin organization in this category of water policy model. Local and regional authorities act as an agent to purchase water from the national system, and resell it to the consumers who are residents living in the municipal boundaries.

The study of OECD (2011) employs a tool proposed by Charbit (2011) to evaluate water governance challenges in 17 OECD countries (Table 1). With the approach called Multi-level governance framework, they point out several challenges or governance "gaps" in the design and regulation of water policy in member countries. The gaps in water governance vary and depend on style of government, traditions together with economic, environmental and geographical factors. Common challenges for effective co-ordination and implementation of water policies are identified as following:

First, in two-thirds of OECD countries in the sample, the main obstacle to vertical and horizontal co-ordination of water policies is the mismatch between administrative responsibilities and available funding or fiscal gap.

Second, the second most important challenge for OECD countries is the capacity gap at the sub-national level although the water service is supported by well-developed infrastructure and regular mobility of expertise.

Third, the lack of institutional incentives for horizontal co-ordination and the fragmentation of responsibilities at national and sub-national level are another policy gap that faces two-thirds of OECD countries in the sample.

Fourth, the mismatch between hydrological and administrative boundaries results in a significant impact on water policy implementation despite the fact that river basin management principles are adopted. 
Model No. 1

Implementing an integrated

and placed-based approach

at the territorial level

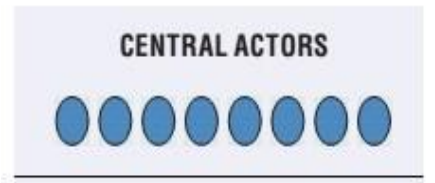

Key challenges:

co-ordination across ministries and

between levels of government

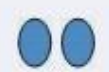

SUBNATIONAL ACTORS

Examples: Korea, Chile, Israel
Model No. 2

Integrating the involvement of different actors at central and subnational levels

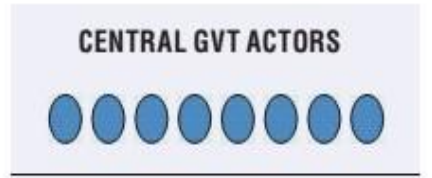

Key challenges: co-ordination across ministries, between levels of government and across local actors

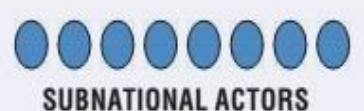

Examples: France, Mexico, Spain
Model No. 3 Integrating multisectoral and territorial specificities in strategic planning and design at central level

CENTRAL GVT ACTORS

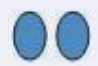

Key challenges: co-ordination across subnational actors and between levels of government

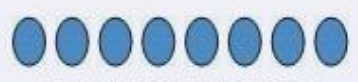

SUBNATIONAL ACTORS

Examples: United States, Canada, Belgium, Australia

Figure 1. Modelling of water governance in selected OECD countries

Source: OECD (2011)

\section{Table 1}

A diagnosis tool for co-ordination and capacity challenges
Information Gap
Asymmetries of information (quantity, quality, type) between different stakeholders, either voluntary or not.
$\Rightarrow$ Need for instruments for revealing \& sharing information.
Capacity Gap Insufficient scientific, technical, infrastructural capacity of local actors, in particular for designing appropriate strategies.
$\Rightarrow$ Need for instruments to build local capacity.

Funding Gap

Unstable or insufficient revenues undermining effective implementation of responsibilities at sub-national level or for crossing policies.

$\Rightarrow$ Need for shared financing mechanisms. 


\begin{abstract}
Policy gap Sectoral fragmentation across ministries and agencies.
$\Rightarrow$ Need for mechanisms to create multidimensional/systemic approaches at the sub national level, and to exercise political leadership and commitment.

Administrative Gap "Mismatch" between functional areas and administrative boundaries.

$\Rightarrow$ Need for instruments for reaching "effective size".

Objective Gap Different rationalities creating obstacles for adopting convergent targets.

$\Rightarrow$ Need for instruments to align objectives.

Accountability Gap Difficulty to ensure transparency of practices across the different constituencies. $\Rightarrow$ Need for institutional quality measurement.

$\Rightarrow$ Need for instruments to strengthen the integrity framework at the local level.

$\Rightarrow$ Need for instruments to enhance citizen's involvement.
\end{abstract}

Source: Charbit (2011)

Fifth, in half of the OECD countries in the sample, information and accountability gaps are also referred to as main challenge to water policy design and implementation.

A study of Akhmouch (2012) provides an excellent summary of the governance of water policy in Latin American and Caribbean (LAC) countries. The author confirms that access to water is crucial for economic growth, environmental health, social development and a mean for alleviating inequalities. Since $70 \%$ of the world's water use is for agricultural production, effective water policies is essential to augment food security and moderate poverty in LAC countries. The improvement of water government can enhance the achievement of water and sanitation indicators in the international Millennium Development Goals (MDGs). It is predicted that the achievement of water MDGs in LAC countries can lift 118 million people out of poverty providing that more specific attention is directed to rural areas.

Although there is a wide variety of missions and capabilities across ministries and government levels, water governance in LAC countries show a substantial decentralization of some functions. Decision on service delivery is often assigned to the local level, while issues related to resources management is decentralized to the higher-tier local governments such as regions, provinces. In the study, the federal and unitary countries in LAC show various differences in the institutional organization of water policy; but the central governments in LAC federal countries often have a more important role than those in OECD federal countries. Organizations for river basin operation have been established in half of LAC nations in the study, federal and unitary nations very similar, based on institutional characteristics, hydrological concerns, international motivation or laws. Nevertheless, the development of these systems differs greatly.

Similar to the case of OCECD countries, there are three broad models of water governance in LAC countries (Table 2). In the first model, 
the regulatory functions are mainly implemented by ministerial departments and/or public agencies. In the second model, specific regulatory agencies in the water sector take the duties, and the third model, specific actors at national level have significant regulatory powers. These different models have occasionally been merged within a same country because environmental regulation is often made by ministerial departments or agencies, while economic regulation is carried out either at the territorial level (states, provinces, municipalities) or by specific regulatory agencies. However, none is regarded as an ideal model because they are all facing governance challenges (Akhmouch, 2012).

\section{Table 2}

Allocation of regulatory powers at the national level

\begin{tabular}{ll}
\hline Where Regulatory Functions Are Mainly & Example Carried Out \\
\hline Ministrerial department & $\begin{array}{l}\text { Cuba (INRH), Guatemala (MARN), Mexico } \\
\text { (COFERPRIS) }\end{array}$ \\
\hline
\end{tabular}

Specific regulatory agency in the water sector (ARESEP), Dominican

Public agency with specific regulatory powers Mexico (CONAGUA), Brazil (ANA), Peru (ANA)

Source: Akhmouch (2012)

The paper of Akhmouch (2012) also employs the Multi-Level Governance Framework approach of Charbit (2011) to investigate water governance challenges in LAC countries. The author finds that the magnitude of governance gaps is different across countries, but there are common trends:

The basic difficulty most LAC countries in the survey is the policy gap. The accountability gap and the funding gap are the second and the third most important challenges in LAC countries. Information and capacity gaps are also imperative in two-thirds of LAC countries surveyed. However, the study highlights that multi-level challenges in water policy analysis needs a comprehensive approach to co- ordination, as they are interconnected and probably aggravate each other. For example, a country having a sectoral fragmentation of water roles and responsibilities across ministries and public agencies (policy gap) are more likely endure the conflicting goals of these public actors (objective gap). Due to silo approaches, policy makers tend to keep information for themselves (information gap). Then this will weaken capacity-building at the sub-national level (capacity gap) as local actors, users and private actors need to increase their efforts to recognize the right interlocutor in the central administration. 


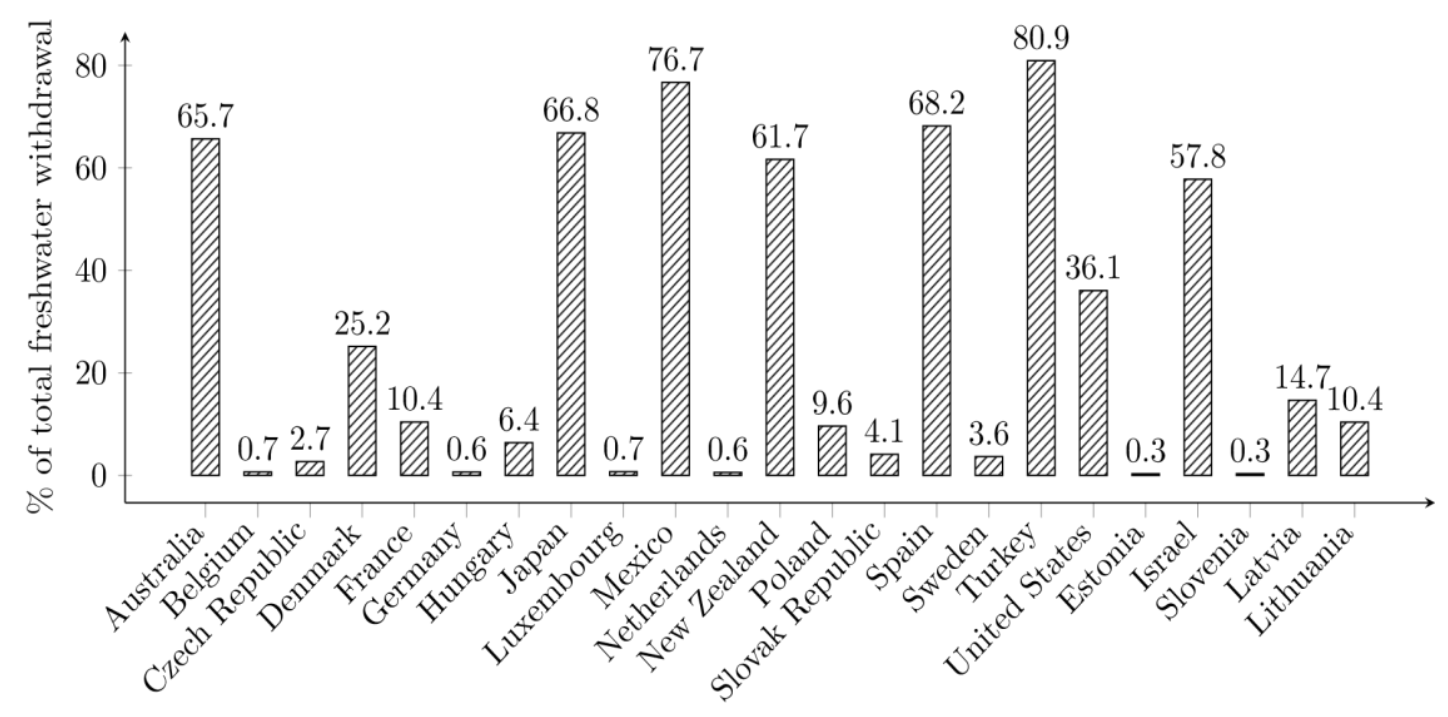

Source: World Bank Open Data.

Figure 2. Annual freshwater withdrawals for agriculture in OECD countries, 2014

A comprehensive study on the water resources management for sustainable agriculture in OECD countries is the work of Parris (2010). The author shows that water shortages due to the phenomena of urbanization, industrialization, and climate change have put a great pressure on food production across the world when demand for food is expected to increase in the upcoming years. Therefore, water resources need to be harnessed and managed efficiently, especially in agricultural activities that use up to $70 \%$ of the worlds freshwater withdrawals (see Figure 2). It is the responsibility of both water managers and water users to distribute water resources effectively as well as equivalently in agriculture so that it can bring in economic, social, and environmental gains. The measures involve: (i) the control of water supply for irrigation and rain-fed agriculture, (ii) the regulation of floods, droughts, and drainage, and (iii) conservation of ecosystems that embrace not only cultural but also recreational values.

The study shows that managing water resources in agriculture is related to the management of surface water, groundwater, rainwater, treated wastewater, and desalinated water. In addition, climate change leaves on its path droughts and floods in some parts of the world when it makes rainfall patterns variate fiercely across different regions, which causes the economy in general and agricultural sector in particular incur a huge economic cost. Hence, the study delivers some key policy notes: (i) Design water resources policies with flexibility; (ii) Improve institutions and property rights; (iii) Charge for the use of water resources; (iv) Integrate various policies; (v) Augment ability to cope with climate change; and (vi) Acknowledge deficiency of knowledge and information.

\section{Water governance in Vietnam: Past and current policies}

\subsection{Background}

The Mekong River Delta is a flat, low-lying, and fertile land stretching an area of $49,520 \mathrm{~km}^{2}$ 
only 0.5 and 3 meters above the sea level. Vietnam covers $74 \%$ of the basin, approximately $39,000 \mathrm{~km}^{2}$, of which $24,000 \mathrm{~km}^{2}$ are utilized for agriculture and aquaculture and $4,000 \mathrm{~km}^{2}$ for forestry (White et al., 2002). Rice crops as well as fish and shrimp aquaculture are the two profitable activities in this region, contributing a lot to GDP every year. However, the increasing use of chemical fertilizers, herbicides, and pesticides in the cultivation of crops for productivity growth has led to a severe damage in fresh water used to raise fish and shrimp. Because much of the surface water is exhausted due to agricultural activities, groundwater is increasingly extracted to meet the growing demands for domestic use. Besides, the basin is one of the places vulnerable to the variation of rainfall distribution, which results in extreme droughts in the dry season and terrible floods in the rainy season each year. Floods in this region come from the three main sources: rainfall or storms, the overflow of dams, and tsunami. El Nio phenomenon in recent years has brought the most severe droughts to the delta for the first time in history (Nguyen et al., 2007).

While water resources in the rainy season are abundant, the basin faces water shortages when the water discharge in upstream of Mekong River declines in the dry season. The drought recorded in the year 2016 has caused the most extensive salinity intrusion in this region for the last 90 years, resulting in the reduction of agricultural production, the depletion of groundwater, and the vulnerability of the livelihoods (Christopher, 2012).

Earlier this year, statistics from the report of CGIAR Research Centers in Southeast Asia (research team from CGIAR Research Centers in Southeast Asia 2016) shows that 13,000 ha of cash crops, 25,500 ha of fruit trees, and 14,400 ha of aquaculture were affected, more than 224,552 ha of rice were heavily intruded by salt, and 208,394 households lacked freshwater for daily use. Climate change is blamed for what happened in the Mekong River Delta over the last 20 years, including the increase in rainfall, extreme weather events, average temperatures, sea level, and salinity intrusion.

\subsection{Water use}

An estimated $82.03 \mathrm{~km}^{3}$ of the total annual water is withdrawn every year for agricultural, industrial, and municipal activities, of which irrigation in agriculture accounts for $77.75 \mathrm{~km}^{3}$ (94.8\%), industrial fields $3.07 \mathrm{~km}^{3}(3.7 \%)$, and municipal sectors $1.21 \mathrm{~km}^{3}(1.5 \%)$. In addition, surface water and ground water withdrawal were approximately $80.45 \mathrm{~km}^{3}(98.1 \%)$ and $1.40 \mathrm{~km}^{3}$ $(1.7 \%)$ respectively. However, the reuse of treated wastewater was about 175 million $\mathrm{m}^{3}$, representing only $0.2 \%$ of the total water withdrawal (Karen, 2011). Although agricultural production helps eradicate and ensures food security, it consumes the largest amount of water resources among other sectors. The annual fresh water withdrawals for agriculture are up to $95 \%$ of the total fresh water (IGES, 2015), the highest among South-East Asian countries (see Figure 3). In addition, the growing demands of domestic and industrial water use in the last decade have also led to the depletion of water resources. Environmental degradations rooted from the expansion of urban population, irresponsible management of solid waste as well as domestic and industrial wastewater, deforestation, and activities for development are the causes leading to water shortages in Vietnam (IGES, 2012). 


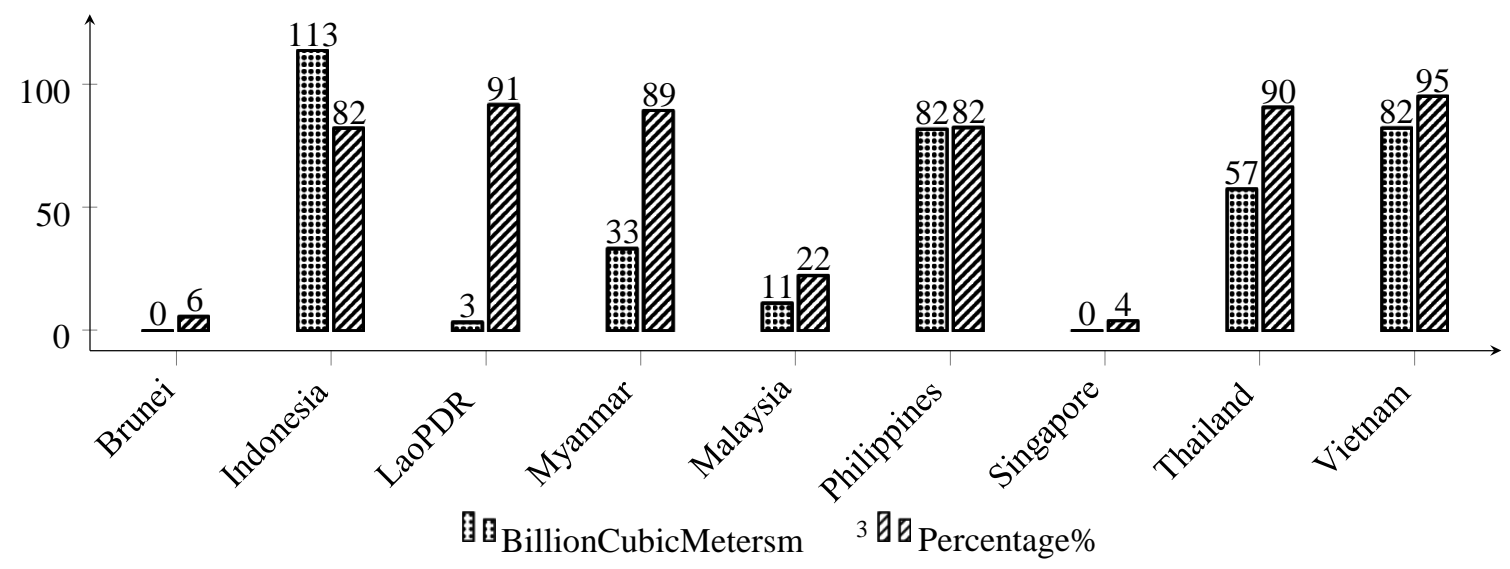

Figure 3. Annual freshwater withdrawals in South-East Asian countries, 2014

Source: World Bank Open Data. The values of Brunei and Singapore are rounded to zero.

\subsection{The pollution of water resources}

The higher level of organic particles from both domestic and industrial waste has polluted rivers, lakes, ponds, and canals within cities across the country. Pollution increases to the highest level in the dry season when little water flows into rivers. Recently, surface water in the basins is seriously contaminated due to the uncontrolled discharge of wastewater. According to the IGES (2015) on Vietnam's urban wastewater, only about $10 \%$ of the total wastewater is treated properly. Although 24 wastewater treatment plants are operating with a total capacity of $670,000 \mathrm{~m}^{3} /$ day, more than one million cubic meters per day of untreated industrial wastewater, about $70 \%$ of the total industrial effluent discharge, is still released directly into water bodies.

Surface water: Although the total surface water in the Mekong River Delta is about 830$840 \mathrm{~km}^{3} /$ year, Vietnam only owns $37 \%$ of the total. Because of the rapid increase in urbanization, the prolonged water shortages and salinity intrusion in the dry season, and climate change, the total surface water resources are predicted to decrease up to $96 \%$ by 2025 . The surface water resources in Vietnam are 848 $\mathrm{km}^{3} /$ year on average; however, the runoff is only $15-30 \%$ of this total in the dry season. Moreover, only about $323 \mathrm{~km}^{3} /$ year (38\%) is generated within Vietnam, while the rest depends on its neighboring countries accounting for $470.1 \mathrm{~km}^{3}$ (IGES, 2015).

Ground water: Ground water resources in Viet Nam are quite plentiful with total potential exploitable reserves of nearly 60 billion $\mathrm{m}^{3}$ / year. However, in reality, just less than $5 \%$ of the total reserves are employed. Most of the water supply units in cities and towns use drilled wells for their operation to extract water under the ground. Hanoi and Ho Chi Minh City are the two cities that pump the largest amount of groundwater. In the Mekong River Delta, the average depth of drilled wells is more than $300 \mathrm{~m}$ for a drilled hole. The total estimated reserves of groundwater in the country are nearly 20 million $\mathrm{m}^{3}$, and the total pumping capacity of urban water supply plants is about 1.47 million $\mathrm{m}^{3} /$ day (IGES, 2015). The exploitable groundwater resources are about 6-7 $\mathrm{km}^{3} /$ year. An investigation in 13 provinces in the Mekong River Delta in 2010 indicated that 553,135 
exploitation wells extract a total of $1,923,681$ $\mathrm{m}^{3} /$ day ground water, of which 552,203 wells exploit less than $200 \mathrm{~m}^{3} /$ day and 932 wells have a capacity greater than $200 \mathrm{~m}^{3} /$ day. 551,507 wells are now employed for domestic $(801,730$ $\mathrm{m}^{3} /$ day $)$, agricultural $\left(769,619 \mathrm{~m}^{3} /\right.$ day $)$, and industrial use (352,332 $\mathrm{m}^{3} /$ day) (Kyoochul Ha \& Jayakumar, 2015).

Continuous reduction in ground water level has been observed in the Mekong Delta Region. The maximum decrease in ground water is $5.0 \mathrm{~m}$ in parts of Ca Mau, Bac Lieu, Kien Giang, and Tra Vinh Provinces; $12.5 \mathrm{~m}$ in parts of Bac Lieu and $\mathrm{Ca}$ Mau Province; $14.2 \mathrm{~m}$ in parts of Ca Mau and Soc Trang Province; $17.6 \mathrm{~m}$ in parts of Bac Lieu, Kien Giang, Tra Vinh, and Can Tho Province; $19.8 \mathrm{~m}$ in parts of Ca Mau, Dong Thap, and Can Tho Province; $25.8 \mathrm{~m}$ in parts of Long An and Tien Giang Province. Recently, due to overexploitation of groundwater in some parts of the Mekong River Delta, this region is facing the decrease in water tables and the increase in land subsidence as well as salinity intrusion. Saltwater intrusion in the region is mainly affected by floods, fresh water supply from the upstream in the dry season, the summer-autumn paddy production, and the timing of the rainy season. The saline density often reaches the highest at the end of the dry season annually. The length of $1 \mathrm{~g} / \mathrm{l}$ salinity intrusion ranges from 40 to $50 \mathrm{~km}$ inland, shorter in the branches of the Mekong River and longer in those of the Vam Co River. Compressible subsidence layer rates average $1.6 \mathrm{~cm}$ per year. In the Mekong River Delta, ground water is seriously intruded by salt on the large scale as well as affected by serious microorganism and heavy metal pollution due to unplanned pumping and the lack of protection of water sources.

\subsection{Historical and political contexts of water management}

Water resources management in Vietnam has a long tradition from its early civilization. It relates to the building of large-scale hydraulic works (dykes, canals) to provide freshwater for agricultural production. The Vietnamese Mekong Delta (VMD) offers a good example for the historical understanding of how water resources have been managed through the opening-up and closing-off processes of the delta (Miller, 2007). The excavation of three primary canals (Bao Dinh, Thoai Ha, and Vinh Te) in the 18th century aimed to strengthen national defense and exploit land for settlements and rice cultivation. From the colonial period until the end of Vietnam War in 1975, a greater number of canals were built in attempts to construct new settlements, improve transportation to rural areas, and implement flood control programs (Biggs, 2003). The post-war period has witnessed the significant intervention of the state in the water sector. National policies for food security and increasing demands for rice export in the 1990s proposed that large-scale schemes need to be continuously invested. Priorities for irrigation development to increase rice production through agricultural intensification and improve farmers standard of living (income) through crop diversification and aquaculture have triggered the extensive development of hydraulic structures, especially in the floodprone areas of the delta (Hoanh et al., 2014).

The dismantling of the centrally-planning economic system from the Vietnamese Doi Moi (Renovation) policy in the early 1980s has dramatic effects on the water resources management. This policy suggests the political attempts of the state to modernize the local agricultural systems and to expand the areas for rice production. In this context, the central government began to transfer their 
administration on the operation and management of hydraulic infrastructure into provincial authorities and lower administrative units. Consequently, various water management schemes have been built, which rendered greater divergence in management approaches and practices. The enactment of the first Law on Water Resources (LWR) (No. 08/1998/QH10) in January 1999 that aims to provide a legislative framework for the water sector reveals limitations and gaps in policies and practices at the central and local level (Loan, 2012). The transfer of water resources management tasks and functions from MARD to MONRE (Ministry of Natural Resources and Environment) caused confusion and conflicts in enforcement (Waibel, 2010). At the river basin level, the establishment of three river basin organizations (RBO): Red River, Dong Nai River, and Mekong River in 2001 aims to perform various functions related to the supply, distribution, protection, and allocation of water (Taylor \& Wright, 2001). However, these institutions do not work effectively as it is expected (Waibel et al., 2012). As argued by Trang (2005), water resources management practices tend to be substantially divergent. Local governments strongly adhere to their unilateral development purposes, instead of gearing into integrative and collaborative approaches for the sustainable development of the river basin as the whole. This undoubtedly drives the dissimilar approaches and practices of water resources management on the ground.

\subsection{Approaches and practices of water management}

4.5.1. Water resources management models in Vietnam

Flood control and drainage constitute key component in the water resources management in the North, Central and South of Vietnam (Bruns, 1997). Sustained efforts to control floods and provide irrigation for agricultural production has prompted the emergence of a wide range of water management approaches and practices initiatives. Nevertheless, these paradigms have brought about both benefits and challenges that need to be revisited.

PIM (Participatory Irrigation Management) plays a key role in increasing agricultural productivity (ADB, 2012). In Vietnam, this approach has been implemented over the last decades, particularly in Northern provinces. Farmers, households, and community based organizations can participate in managing water resources (Benedikter \& Waibel, 2013). The grassroots democratization and the policy slogan 'The State and people work together', give more willingness to farmers in participating in irrigation management. There are various PIM models that have been effectively operated across the country (Tiep, 2008).

However, there are arguments that PIM approach is not fully successful in practical terms (Dung \& Shivakoti, 2007; Tiep, 2008). In the study in Bac Kan and Tuyen Quang provinces, Dung and Shivakoti (2007) commented that the application of PIM reveals much gap and inappropriateness. Four key reasons attributed to the challenges of PIM include: (i) the absence of a clearly-defined system of rights and responsibilities of stakeholders in the process of PIM; (ii) the inconsistency of PIM adoption constraining active participation of farmers in irrigation management; (iii) the lack of comprehensive implementation strategy of PIM at the national level; and (iv) the lack of political will and proper attention of some high-ranking officials in supporting PIM.

IWRM (Integrated Water Resources Management) can be seen as "the most appropriate overall strategy for managing water resources" (Gain et al., 2013). It is defined as "the process which promotes the coordinated development and management of water, land and 
related resources, in order to maximize the resultant economic and social welfare in an equitable manner without compromising the sustainability of vital ecosystems" (GWP, 2000). In Vietnam, the IWRM approach has received growing recognition from the early 2000s. Although the IWRM principles were integrated into the LWR and the National Water Resources Strategy toward 2020, reality suggests that the water management practices largely deviate from the IWRM principles. In the VMD for instance, provincial authorities tend to set up their own institutional arrangements in the operation and management of hydraulic structures to accommodate local hydrological conditions and socio-economic development policies. The implementation of these water management practices is mainly locally oriented rather than complying with the IWRM principles prescribed by the State. Various water management paradigms do not include the collaborative management of floodwaters in the development agenda. Negative impacts of flood alterations relate to the absence of institutional collaboration in flood management and planning (Tuan et al., 2007; Hoa et al., 2007, 2008). There are also increasing complaints regarding 'dyke versus non-dyke areas or upstream versus downstream'.

Characterized by the PIM principles, the community-based water management approach aims to promote the participation of rural communities in the local decision-making process. Regarding flood control and irrigation management in the VMD, this approach has been adopted to boost agricultural production. However, there are dark sides of this approach. Local communities are not fully engaged in the decision-making and planning processes, thus their contribution to the flood control and irrigation management is minimal.

4.5.2. Assessment of water management schemes in the MDV
The Bac Vam Nao flood control scheme (BVN) is a successful collaborative water management model in the VMD (Figure 4). It is the AusAID-funded project in collaboration with the government of An Giang province (AusAID, 2007). The project area spans 22 administrative units of Tan Chau district (12\%) and Phu Tan district (88\%) of An Giang province (Tuan et al., 2015). The main goal of the project is to control high floods and promotes intensive rice production in the area.

This initiative characterizes some key aspects of the PIM approach (AusAID, 2007). The IWRM principles are also incorporated in the design and construction of the project through the coordinated approach to water and land management (Tuan et al., 2015). The scheme introduces the modern and innovative sets of institutional arrangements that align with the national agenda in public administration reforms,

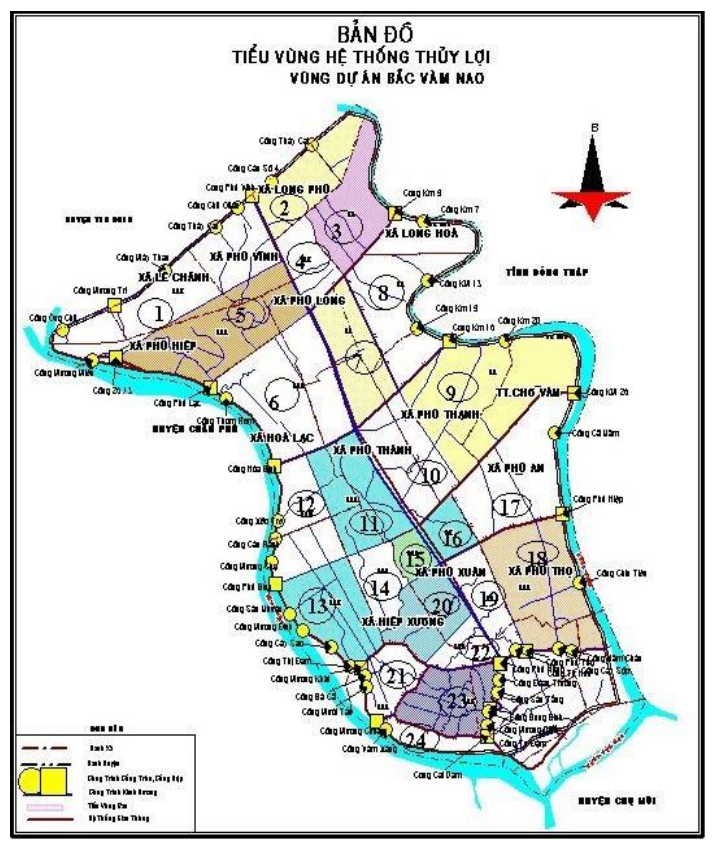

Figure 4. Compartments of the NVN flood control scheme

Source: An Giang Agency of Water Resources (2013) 
decentralization, and regulations concerning grassroots democratization. It combines the hierarchical administration with participatory approach for flood management (Figure 5). According to Thong (2016), the effective performance of the scheme is largely attributed to the 'experimentation' of the Australian partner's participatory governance arrangements in local flood management and the mobilization of multiple sources of knowledge from the relevant stakeholders. Local farmers can participate in the process of planning, operation and management of the scheme. Some entities are established to provide practical assistance to farming communities. For instance, compartment management boards (CMBs) play an important role in representing farmer's rights and responsibilities in response to local governments. Facilitated by the CMBs, farmers can raise their voices that can feed into the local decision-making process (Thong, 2016). Despite its demonstrated success, this water management scheme has not been widely adopted in the VMD as it encounters challenges associated with the institutional formulation of local water management units, high investment costs, and the willingness of local administrations. The Omon-Xano scheme is built in the lower part of the VMD. This hydraulic system aims to prevent the saline intrusion, control floods for agricultural production and provide favorable conditions for aquatic transport in the area (Tuan et al., 2015). Unlike the BVN, the Omon-Xano scheme does not comply with PIM principles. It is jointly managed by three adjacent provinces in the delta: Can Tho, Hau Giang and Kien Giang. However, the construction of this project has not yet been completed and does not work effectively on the ground (Tuan et al., 2015). This could be attributed to the absence of collaborative arrangements in the operation of the irrigation system among the provinces. The localized policies of irrigation and water control pose multiple challenges for the sustainable development of the VMD. Critical debates on whether control- or adaptation-oriented development policies should be adopted have been raised, but so far not pertinently addressed. Solving this conundrum, by all means, is not easy, especially in the ongoing contexts of climate change and hydropower dam development in the Mekong Basin. In response to these emerging complexities, the 'living with floods' approach suggests that pro-adaptation measures need to be taken as the key strategy to achieve the sustainable development in the VMD.

\section{Policy implication for sustainable development in the Mekong Delta region}

Observed drawbacks of the existing water management approaches combined with external factors (incremental impacts of climate change and upstream development dynamics) have caused the forced adaptation complexities we are faced with (Thong, 2016). They have engendered numerous constraints, placing the livelihoods of the millions of the local inhabitants at high risks. In the sector of water management, there should be policy solutions that go practically into local needs and adapt to the emergent issues. Several suggestions that guide adaptation policies are presented as follows: 


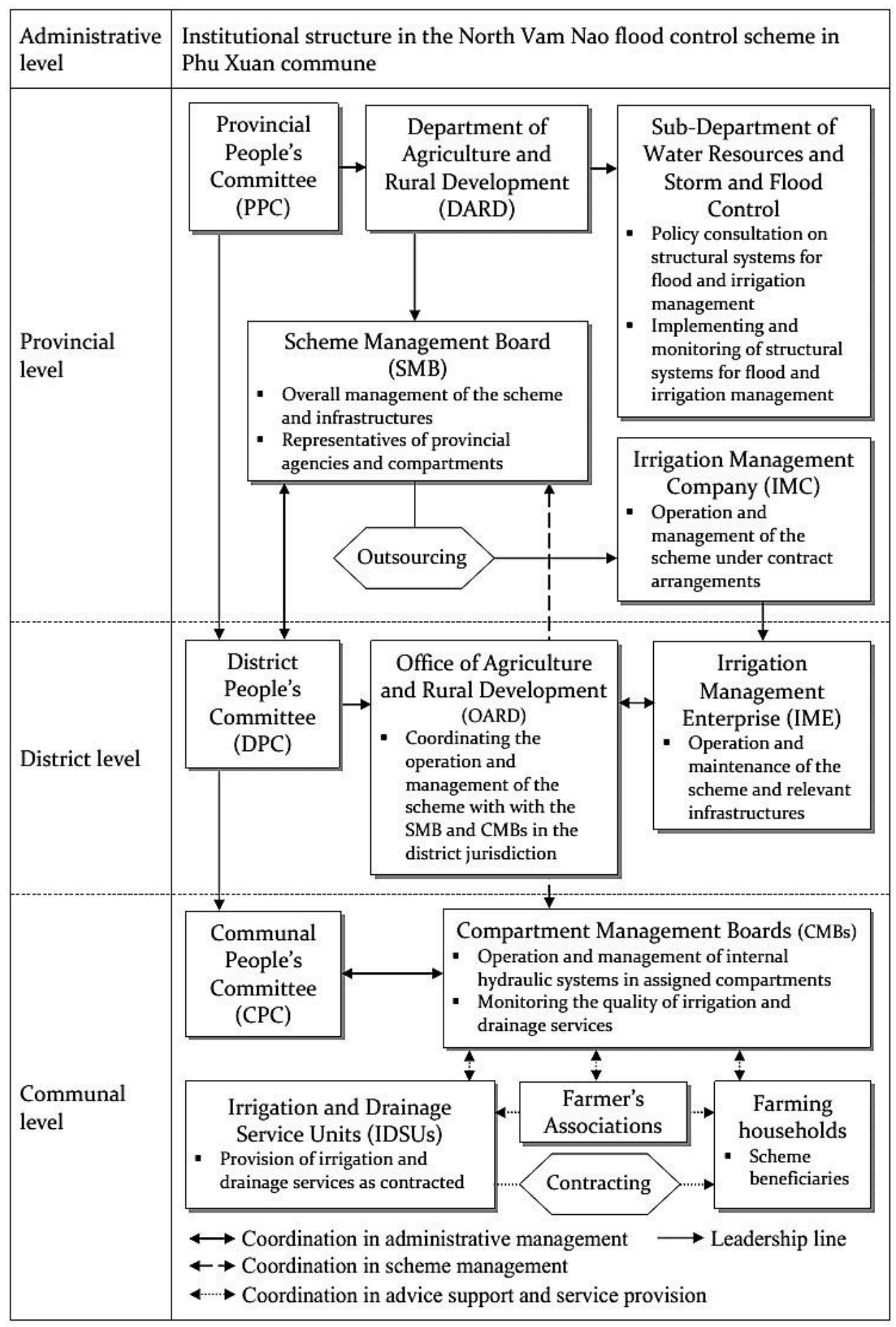

Figure 5. Institutional framework for the North Vam Nao flood control scheme 
First, there is a promise for the extrapolation of successful water management models in the localities (e.g. the NVN project) that share similar hydrological conditions. However, this usually encounters limitation in financial and human resources. In practical terms, we need to explore alternative measures (small-scale) that would probably better suit 'real-life' situations.

Second, given different pathways and demands for local development, provinces that share the borders need to formulate interjurisdictional governance arrangements on water management. This is critically important to harmonize their socio-economic benefits and support the majority of population who rely on water-related resources for livelihoods. At the same time, adaptive measures which are based on the 'learning-by-doing' approach should be taken to guide adaptation behaviors.

Third, locally-managed water systems need to align with the judicious application of experiential and experimental knowledge built over time. There need the interactions and communication between government and local communities in sharing knowledge in order to collectively tackle the water management constraints. Participation of farming communities in irrigation and water resource management needs to be formally recognized and incorporated in the planning and decisionmaking processes. This institutional change helps address policy gaps in traditional water management approaches. Local governments should demonstrate their responsibilities and strong commitment in water management. They should be accountable for their actions.

In addition, for the sustainable use of water in the Mekong River Delta, water supply companies and water consumers for agricultural, industrial, and domestic use need to cooperate with each other to manage surface and ground water properly. Following are some measures that can be taken to promote sustainable groundwater usage in the Mekong River Delta:

Fourth, limit the amount of ground water abstracted: (i) using ground water with high quality to supply for the domestic drinking water; (ii) exploring sources of groundwater that are lost or misused and making a proper plan for exploitation; (iii) solving leaking wells, pipes, and tubes that waste ground water; (iv) applying alternative solutions such as (a) growing salinetolerant crops and $(b)$ treating waste water in industry for aquaculture and agriculture; and $(v)$ optimizing water extraction with the help of knowledge about the local subsurface structure as well as its hydraulic characteristics.

Fifth, increase recharge of ground water: (i) using technologies to increase groundwater recharge with artificially infiltrated precipitation and identify low saline surface water; and (ii) conducting studies to minimize long-term risks by carefully examining the impacts of hydrogeology on the subsurface environment and to develop appropriate geotechnical and monitoring strategies for water management 


\section{References}

ADB. (2012). Participatory irrigation management: How can participation contribute to the sustainable management of irrigation and drainage systems for agriculture? Learning lessons. Technical report, Asian Development Bank.

Akhmouch, A. (2012). Water governance in Latin America and the Caribbean. Organisation for Economic Co-operation and Development, Paris.

Asefa, S. (2005). The economics of sustainable development. WE Upjohn Institute.

AusAID. (2007). Vietnam: Integrated water management plan, techreport. Australian Agency for International Development, North Vam Nao Water Control Project II.

Benedikter, S., \& Waibel, G. (2013). The formation of water user groups in a nexus of central directives and local administration in the Mekong Delta, Vietnam. Retrieved from https://www.researchgate.net/publication/257652462_The_formation_of_water_user_groups_in_ a_nexus_of_central_directives_and_local_administration_in_the_Mekong_Delta_Vietnam

Biggs, D. (2003). Problematic progress: Reading environmental and social change in the Mekong Delta. Journal of Southeast Asian Studies, 34(1), 77-96.

Brundtland, G., Khalid, M., \& Agnelli, S. (1987). Our common future: Report of the 1987 world commission on environment and development. United Nations, Oslo.

Bruns, B. (1997). Participatory management for agricultural water control in Vietnam: Challenges and opportunities. National Seminar on Participatory Irrigation Management.

CGIAR. (2016). The drought and salinity intrusion in the Mekong River Delta of Vietnam. Technical report. International Rice Research Institute (IRRI).

Charbit, C. (2011). Governance of public policies in decentralized contexts: The multi-level approach. Regional Development Working Papers. OECD.

Christopher, J. (2012). The impact \& management of floods \& droughts in the lower Mekong basin \& the implications of possible climate change. Technical report. Mekong River Commission, Flood Management and Mitigation Programme.

Cooley, H., Christian-Smith, J., Gleick, P. H., Allen, L., \& Cohen, M. (2009). Understanding and reducing the risks of climate change for transboundary waters. Pacific Institute, Oakland, CA.

Cosgrove, W., \& Rijsberman, F. (2000). World water vision: Making water everybody's vision. Earthscan, London. 
DFID. (2005). Meeting the water and sanitation millennium development goal. Technical report. Department for International Development.

Dukhovny, V. A., \& Ziganshina, D. (2011). Ways to improve water governance. Irrigation and Drainage, 60(5), 569-578.

Dung, P. T., \& Shivakoti, G. P. (2007). Southeast Asian water environment 2. Participatory irrigation management practices in Vietnam: A pathway in progress towards effective and sustainable use of agricultural water (pp. 75-82). IWA Publishing, London.

European (2000). EU water framework directive, directive 2000/60/ec. European Union.

European. (2007). 60/ec of the European parliament and of the council of 23 October 2007 on the assessment and management of flood risks. Official Journal of the European Union, 288(27).

Franks, T., \& Cleaver, F. (2007). Water governance and poverty a framework for analysis. Progress in Development Studies, 7(4), 291-306.

Gain, A. K., Rouillard, J. J., \& Benson, D. (2013). Can integrated water resources management increase adaptive capacity to climate change adaptation? A critical review. Journal of Water Resource and Protection, 5(04), 11-20.

GWP. (2000). Integrated water resources management. Technical report. Global Water Partnership, Stockholm.

Hayward, S. F. (2003). A sensible environmentalism. Public Interest, (151), 62.

Hoa, L. T. V., Nguyen, H. N., Wolanski, E., Tran, T. C., \& Haruyama, S. (2007). The combined impact on the flooding in Vietnam's Mekong River Delta of local man-made structures, sea level rise, and dams upstream in the river catchment. Estuarine, Coastal and Shelf Science, 71(1), 110 116.

Hoa, L. T. V., Shigeko, H., Nhan, N. H., \& Cong, T. T. (2008). Infrastructure effects on floods in the Mekong River Delta in Vietnam. Hydrological Processes, 22(9), 1359-1372.

Hoanh, C. T., Suhardiman, D., \& Anh, L. T. (2014). Irrigation development in the Vietnamese Mekong Delta. International Journal of Water Governance, 2(2-3), 61-82.

IGES. (2012). Wepa outlook on water environmental management in Asia. Technical report. Institute for Global Environmental Strategies (IGES).

IGES. (2015). Wepa outlook on water environmental management in Asia. Technical report. Institute for Global Environmental Strategies (IGES).

Karen, F. (2011). Irrigation in southern and eastern Asia in figures. Technical report. Food and Agriculture Organization of the United Nations. 
Kundzewicz, Z. W., \& Kowalczak, P. (2009). The potential for water conflict is on the increase. Nature, 459(7243), 31.

Kyoochul, H., Nguyen, T. M. N., \& Jayakumar, R. (2015). Current status and issues of groundwater in the Mekong River Delta. Technical report. Korea Institute of Geoscience and Mineral Resources (KIGAM), CCOP Technical Secretariat, and UNESCO Bangkok Office.

Loan, N. T. P. (2012). Legal framework of the water sector in Vietnam: Achievements and challenges. Journal of Vietnamese Environment, 2(1), 27-44.

Miller, F. (2007). Seeing 'water blindness': Water control in agricultural intensification and environmental change in the Mekong Delta, Vietnam. In J. Connell \& E. Waddell (Eds.), Environment, development and change in rural Asia-Pacific: Between local and global (pp. 186-207). Routledge Taylor \& Francis Group, London.

Nguyen, H. N., Vu, K. T., \& Nguyen, X. N. (2007). Flooding in Mekong River Delta, Vietnam. Human Development Report, 2008, 23.

OECD. (2011). Water governance in OECD countries: A multilevel approach. OECD Publishing.

Pahl-Wostl, C., Gupta, J., \& Petry, D. (2008). Introduction: Global governance of water. Global Governance: A Review of Multilateralism and International Organizations, 14(4), 405-407.

Parris, K. (2010). Sustainable management of water resources in agriculture. Technical report. OECD.

Rogers, P. (2002). Water governance in Latin America and the Caribbean. Sustainable Development Department, Environment Division, Inter-American Development Bank.

Rogers, P., \& Hall, A. W. (2003). Effective water governance. Vol. 7. Global water partnership.

Solanes, M., \& Jouravlev, A. (2006). Water governance for development and sustainability. Vol. 111. United Nations Publications.

Taylor, P., \& Wright, G. (2001). Establishing river basin organisations in Vietnam: Red River, Dong Nai River and lower Mekong Delta. Water science and technology, 43(9), 273-281.

Thong, T. A. (2016). Flood governance in the Mekong Delta of Vietnam: Implications of social learning for household and institutional adaptation. ANU College of Health \& Medicine.

Tiep, N. X. (2008). PIM models in Vietnam-experience lessons. Vietnam National Committee on Large Dams and Water Resources Development

Trang, T. T. Q. (2005). Water resources management in Vietnam. Workshop on the water in mainland Southeast Asia, Siem Reap, Cambodia.

Tuan, L. A., Hoanh, C. T., Miller, F., \& Sinh, B. T. (2007). Flood and salinity management in the Mekong Delta, Vietnam. In T. T. Be, B. T. Sinh \& F. Miller (Eds.). Challenges to sustainable 
development in the Mekong Delta: Regional and national policy issues and research needs: Literature analysis (pp. 15-68). The Sustainable Mekong Research Network (Sumernet), Bangkok, Thailand.

Tuan, L. A., Minh, H. V. T., Tuan, D. D. A., \& Thao, N. T. P. (2015). Baseline study for communitybased water management project. Technical report, Mekong Water Governance Program Vietnam.

UN. (2005). Health, dignity and development: What will it take? Technical report. Stockholm International Water Institute \& United Nations Millennium Project, United Nations.

UNDP. (2007). Coping with water scarcity: Challenge of the twenty-first century. World Water. United Nations Development Programme.

Waibel, G. (2010). State management in transition: Understanding water resources management in Vietnam. Technical report. Center for Development Research, University of Bonn.

Waibel, G., Benedikter, S., Reis, N., Genschick, S., Nguyen, L., Huu, P. C., \& Be, T. T. (2012), Water governance under renovation? Concepts and practices of IWRM in the Mekong Delta, Vietnam. In The Mekong Delta system (pp. 167-198). Springer Netherlands.

White, I. (2002). Water management in the Mekong Delta: Changes, conflicts and opportunities. UNESCO Paris.

WWAP. (2003). Water for people, water for life. United Nations World Water Development Report. UNESCO Division of Water Sciences, Paris.

WWC. (2006). Ministerial declaration of the fourth world water forum. World Water Council and the Secretariat of the 4th World Water Forum, Mexico.

WWC. (2015). Ministerial declaration of the seventh world water forum. Ministerial Process, 13 April 2015. Gyeongju, Korea. 